\title{
Are There Changes in English Learning Strategies Used by Chinese Students after They Study in Thailand?
}

\author{
Rosukhon Swatevacharkul, Ph.D.
}

\author{
Assistant Professor \\ Department of English, the Faculty of Arts \\ Dhurakij Pundit University, Bangkok, Thailand
}

Doi:10.5901/jesr.2013.v3n7p292

\begin{abstract}
The use of English learning strategies is not static, and it can be changed or developed over time. The learning environment is one of the possible factors that can cause such changes; however, little attempt has been paid in researching possible influence of the EFL learning environment on English learning strategies used by foreign learners in EFL countries. Therefore, the purpose of this study was to examine if there are changes in English learning strategies used by Chinese undergraduate students after they study in Thailand. This study has taken a survey research approach having as the subjects 218 Chinese undergraduate students in four private universities in Bangkok. Thailand. Chinese language questionnaires were used to collect data. Interviews were also conducted to gain insights. The Chi-square test was used to test the hypothesis, while qualitative data were analyzed by thematic content analysis. Reliability was ensured by intra-rater reliability $\left(r_{x y}=0.970\right)$. The findings revealed that the number of Chinese students who reported that their English learning strategies use change was significantly different from those who reported no such changes after they studied in Thailand $(p<0.05)$. This means that, in general, a larger number of Chinese students have changed their English learning strategies use. English learning strategies of speaking and listening skills were reported as the most frequently influenced.
\end{abstract}

\section{Introduction}

\subsection{English Learning Strategies}

Considering the role of English as a global language and a language for communication in the ASEAN Economic Community (AEC) which will be implemented in 2015, proficiency in English is gaining even greater importance. In Thailand, greater awareness of the significance of English has been widely raised, especially in educational institutions which attempt to improve their students' English proficiency in preparation for the AEC.

In the context of foreign language learning, learning strategies which are extended from and are applications of the cognitive theory, have a very crucial role to play in developing communicative competence as they are steps for language learners to take to facilitate and enhance their own foreign language learning (Oxford, 1990). In addition, in the field of language learning and teaching over several decades, there has been a great emphasis on learners and their learning. Interests have been shown in how learners process new information and what strategies they use to understand, learn, or remember it.

The term 'language learning strategies' is defined in various ways by different scholars in the field. Chamot (1987: 71) defines learning strategies as 'techniques, approaches, or deliberate actions that students take in order to facilitate the learning and recall of both linguistic and content area information'. According to Wenden (1987), learner strategies are referred to as language learning behaviors of learners to learn and regulate the second language learning, learners' knowledge about the learning strategies they use, and learners' knowledge about other aspects of their language learning besides the strategies, and these may affect their selection of strategy used. Rubin (1987: 19) identifies that 'learner strategies include any set of operations, steps, plans, routines used by the learner to facilitate the obtaining, storage, retrieval and use of information'.

Language learning strategies are classified into two major types: direct and indirect strategies (Oxford, 1990). Direct strategies include memory strategies (assisting learners to store and retrieve new information), cognitive strategies (making learners able to understand and produce a new language by many ways ranging from repeating to analyzing expressions to summarizing), and compensation strategies (enabling learners to use the language for either comprehension or production although having no full understanding in language knowledge). Indirect strategies involve 
metacognitive strategies (providing a way for learners to co-ordinate their own learning process), affective strategies (helping language learners control their emotion, attitudes, motivations, and values), and social strategies (involving appropriate interaction with other people during communication).

Oxford (1994) argues that conscious use of the strategies has a positive relationship with language learning achievement and proficiency. Language learning strategies are, therefore, good indicators of how learners approach tasks or problems faced during the language learning process; additionally, they give language teachers valuable clues about how their students learn. However, use of learning strategies is not static, and it can be changed or developed over time, and the learning environment is one of the possible factors that can cause change of strategy use.

Among foreign students studying in Thai universities, Chinese students make up the largest population. The number of Chinese students in the international program has been increasing, and it was approximately 10,000 in 2012 (Naewna, 2013). These students concentrate in business administration, tourism, IT, the sciences and Thai (Xinhua News agency, 2006). Low fees, cultural similarities and the variety of courses on offer are the major reasons for the rising number, and the upward trend is very promising. In terms of research, it is unfortunate that little attempt has been paid on empirical research regarding the possible influence of learning environment on English learning strategy use $(G a 0,2003)$. Therefore, this study aimed to examine if there are changes in English learning strategies used by Chinese students after they study in Thailand. The null hypothesis was set as: there are no significant changes in English learning strategies used by Chinese students after they study in Thailand $(a=0.05)$. This was due to limited existing research findings on this particular issue: use of English learning strategies by foreign students in an EFL context.

\section{Methodology}

\subsection{Subjects}

Drawn from 1,800 Chinese students studying at the 17 private universities in Bangkok, Thailand, with the two-stage random sampling technique, the subjects were 218 Chinese students whose majors were international business, marketing, and finance at the four private universities: Assumption University (ABAC), University of the Thai Chamber of Commerce (UTCC), Rangsit University (RSU), and Dhurakij Pundit University (DPU). They took courses in international $(n=98)$ and Thai ( $n=120)$ programs, using English and Thai as a medium of instruction respectively.

\subsection{Research Design and Instrument}

The study took the form of a survey research design. A questionnaire in Mandarin Chinese (Appendix) was used to collect quantitative and qualitative data. Interviewing was also employed with 8 students -2 from each university to probe and gain insights for data discussions.

\section{Data Analysis}

The Chi-square test $\left(\chi^{2}\right)$ was applied to test the hypothesis. The qualitative data in the Chinese language were translated into English, and then analyzed using the thematic content analysis attempting to derive key words for data categorization. To ensure reliability, 'intra-rater reliability' which is one type of reliability assessment in which the same assessment was completed by the same rater or researcher was used, and a very high correlation between the two ratings was found $\left(r_{x y}=.970\right)$.

\section{Results}

The $\chi^{2}$ produced the result as shown in Table 1 .

Table 1: The Changes of English Learning Strategy Use

\begin{tabular}{|c|c|c|c|c|c|}
\hline Strategy Use & Observed $\mathbf{n}$ & Expected $\mathbf{n}$ & Residual & df & $\chi^{2}$ \\
\hline Changed & 152 & 109 & 43 & 1 & $33.927^{*}$ \\
\hline Not changed & 66 & 109 & -43 & & \\
\hline Total & 218 & & & & \\
\hline
\end{tabular}


Table 1 shows that $.05 \chi^{2}{ }_{1}<33.927$, and the hypothesis is rejected. Therefore, the number of Chinese students who reported a change in their learning strategy use is significantly different from those who reported no change of their strategy use after their study in Thailand $(p<0.05)$. This means that, generally speaking, a larger number of Chinese students have changed their English learning strategy use after they have studied in Thailand.

Cross tabulation was also run to gain further information of changes in English learning strategy use after their study in Thailand in each university (Table 2).

Table 2: Cross Tabulation Showing Changes Reported by Students in each University

\begin{tabular}{|c|c|c|c|c|c|}
\hline \multirow{2}{*}{\multicolumn{3}{|c|}{ University }} & \multicolumn{2}{|c|}{ Learning strategy } & \multirow{3}{*}{$\begin{array}{c}\text { Total } \\
64 \\
100 \%\end{array}$} \\
\hline & & & \multirow{2}{*}{$\begin{array}{c}\text { Changed } \\
43 \\
67.2 \%\end{array}$} & \multirow{2}{*}{$\begin{array}{c}\text { Not changed } \\
21 \\
32.8 \%\end{array}$} & \\
\hline ABAC & inter & $\begin{array}{c}\text { Count } \\
\%\end{array}$ & & & \\
\hline UTCC & inter & $\begin{array}{c}\text { Count } \\
\%\end{array}$ & $\begin{array}{c}19 \\
70.4 \%\end{array}$ & $\begin{array}{c}8 \\
29.6 \%\end{array}$ & $\begin{array}{c}27 \\
100 \%\end{array}$ \\
\hline \multirow[b]{2}{*}{ DPU } & inter & $\begin{array}{c}\text { Count } \\
\%\end{array}$ & $\begin{array}{c}7 \\
100 \% \\
\end{array}$ & $\begin{array}{c}0 \\
0 \% \\
\end{array}$ & $\begin{array}{c}7 \\
100 \% \\
\end{array}$ \\
\hline & Thai & $\begin{array}{c}\text { Count } \\
\%\end{array}$ & $\begin{array}{c}65 \\
68.4 \%\end{array}$ & $\begin{array}{c}30 \\
31.6 \%\end{array}$ & $\begin{array}{c}95 \\
100 \%\end{array}$ \\
\hline $\mathrm{RU}$ & Thai & $\begin{array}{c}\text { Count } \\
\%\end{array}$ & $\begin{array}{c}18 \\
72.0 \% \\
\end{array}$ & $\begin{array}{c}7 \\
28.0 \% \\
\end{array}$ & $\begin{array}{c}25 \\
100 \% \\
\end{array}$ \\
\hline
\end{tabular}

According to Table 2, a higher number of Chinese students in each program of study and in each university reported a change in learning strategy use after their study in Thailand. For ABAC, $67.2 \%$ of the students reported a change while $32.8 \%$ reported no change. $70.4 \%$ of the UTCC students, $100 \%$ of the international program DPU students, and $68.4 \%$ Thai program DPU students changed their learning strategy use. Likewise, $72.0 \%$ of the RU Chinese students reported a change in English learning strategy use.

Table 3: Cross Tabulation Showing Changes of each English Skill

\begin{tabular}{|c|c|c|c|c|c|c|c|}
\hline & \multicolumn{5}{|c|}{ English Skills } & \multirow[b]{2}{*}{ Total } \\
\hline & & Very much & Much & Moderate & Little & Very little & \\
\hline Listening & Count & 56 & $\begin{array}{c}56 \\
37306\end{array}$ & 30 & 5 & 3 & 150 \\
\hline & $\frac{\%}{\text { Count }}$ & $\frac{37.3 \%}{55}$ & $\begin{array}{c}37.3 \% \\
67\end{array}$ & $\frac{20.0 \%}{27}$ & $\frac{3.3 \%}{7}$ & $\frac{2.0 \%}{2}$ & $\begin{array}{c}100.0 \% \\
158\end{array}$ \\
\hline Speaking & $\%$ & $34.8 \%$ & $42.4 \%$ & $17.1 \%$ & $4.4 \%$ & $1.3 \%$ & $100.0 \%$ \\
\hline Reading & Count & 25 & $\begin{array}{c}40 \\
2740\end{array}$ & $\begin{array}{c}69 \\
6730\end{array}$ & $\begin{array}{c}8 \\
5504\end{array}$ & $\begin{array}{c}4 \\
27 \%\end{array}$ & 146 \\
\hline Writing & $\begin{array}{c}\text { Count } \\
\%\end{array}$ & $\begin{array}{c}16 \\
10.6 \%\end{array}$ & $\begin{array}{c}44 \\
29.1 \%\end{array}$ & $\begin{array}{c}50 \\
33.1 \%\end{array}$ & $\begin{array}{c}25 \\
16.6 \%\end{array}$ & $\begin{array}{c}16 \\
10.6 \%\end{array}$ & $\begin{array}{c}151 \\
100.0 \%\end{array}$ \\
\hline Vocabulary & $\begin{array}{c}\text { Count } \\
\%\end{array}$ & $\begin{array}{c}21 \\
14.4 \%\end{array}$ & $\begin{array}{c}33 \\
22.6 \%\end{array}$ & $\begin{array}{c}57 \\
39.0 \%\end{array}$ & $\begin{array}{c}22 \\
15.1 \%\end{array}$ & $\begin{array}{c}13 \\
8.9 \%\end{array}$ & $\begin{array}{c}146 \\
100.0 \%\end{array}$ \\
\hline Total & $\begin{array}{c}\text { Count } \\
\%\end{array}$ & $\begin{array}{c}173 \\
23.0 \%\end{array}$ & $\begin{array}{c}240 \\
32.0 \%\end{array}$ & $\begin{array}{c}233 \\
31.0 \%\end{array}$ & $\begin{array}{c}67 \\
8.9 \%\end{array}$ & $\begin{array}{c}38 \\
5.1 \%\end{array}$ & $\begin{array}{c}751 \\
100.0 \%\end{array}$ \\
\hline
\end{tabular}

Table 3 shows changes of each English skill. Since there were the frequencies of less than 5, the Exact test was used. The results showed that speaking and listening skills were reported as the most changed skills. For speaking, $42.4 \%$ of the students in both programs reported their change of learning strategy use as "much", and $34.8 \%$ rated it as "very much". For listening, $37.3 \%$ of the students perceived the changes equally as "much" and "very much". The other language skills which are reading, writing, and vocabulary were more likely to be perceived as moderate changes.

\subsection{Comparisons of Strategies Used in China and Thailand}

The open-response item questionnaire asked the students to explain what and how learning strategies of the English skill they reported as the most changed. According to the quantified qualitative findings, some students reported that both 
listening and speaking skills were equally the most changed. Therefore, an emphasis will be put on a report of the findings on speaking and listening skills. However, it should be noted that many students did not explain the learning strategies they used for each particular learning strategy; instead, they explained more on factors or reasons causing changes.

\subsubsection{Speaking Strategies}

Table 4 provides comparative details of the speaking strategies used in China and Thailand.

Table 4: Speaking Strategies Used In China and Thailand

\begin{tabular}{|l|c|c||l|c|c|}
\hline Speaking Strategies in China & Frequency & $\%$ & $\begin{array}{l}\text { Speaking Strategies in } \\
\text { Thailand }\end{array}$ & Frequency & $\%$ \\
\hline Try to speak like native speakers & 6 & 17.6 & Find opportunity to speak English & 54 & 87 \\
\hline Practice speaking in class only & 6 & 17.6 & $\begin{array}{l}\text { Watch movies and TV, listen to } \\
\text { songs }\end{array}$ & 8 & 13 \\
\hline Memorize & 2 & 5.8 & & & \\
\hline Little opportunities to speak English & 20 & 59.0 & & & \\
\hline
\end{tabular}

According to Table 4, 59\% reported that they had little opportunity to speak English in China, and did not mention much about speaking strategies. This is understandable. They rarely spoke English in China; therefore, it was uncommon for them to use English learning strategies in relation to speaking English.

The focus is on writing.

Teachers give handouts to study by ourselves. It's a rare opportunity to speak English.

However, $17.6 \%$ reported the speaking strategies of trying to speak like native speakers and practicing speaking English in class only. Memorizing was given $5.8 \%$.

The occurrence of the strategy of trying to speak like native speakers can be explained, as individual Chinese students are typically given a course CD or cassette tape to practice listening and speaking on their own. In terms of speaking, they listen to and try to imitate the English native accents.

Listen to course cassette tapes to practice speaking.

I read the course book, listened to the tape, and practice speaking.

In Thailand, $87 \%$ reported finding opportunities to speak as the first speaking strategy, followed by watching movies and TV, and listening to songs with $13 \%$.

The strategy of finding opportunities to speak included communication with their teachers, class mates in class, and Thai people outside of class. Furthermore, they made an attempt to make more foreign friends to practice speaking English.

The most different part is speaking. In china, we just speak English in class, but here I have to speak English everywhere.

Here, I try my best to speak and learn from other people. Try to understand every word which they say, then use these words for my own speaking.

We have to speak English because if we don't speak, we don't know what other people are talking about, so practice speaking English because we must do homework and assignments every day. We need to take many chances to practice by ourselves.

In conclusion, the findings showed the dramatic different speaking strategies when Chinese students came to and study in Thailand. They make an effort to find opportunities to speak English with teachers, class mates or people outside the class room. In contrast, in China they did not have many opportunities to practice speaking even in the class 
room. Moreover, speaking like native speakers was the very first speaking strategy used while these students were in China.

\subsubsection{Listening Strategies}

Table 5 reveals comparative details of the listening strategies used in China and Thailand.

Table 5: Listening Strategies Used In China and Thailand

\begin{tabular}{|l|c|c||l|c|c|}
\hline $\begin{array}{l}\text { Listening Strategies in } \\
\text { China }\end{array}$ & Frequency & $\%$ & $\begin{array}{l}\text { Listening Strategies in } \\
\text { Thailand }\end{array}$ & Frequency & $\%$ \\
\hline Practice through media & 13 & 39.4 & Practice through media & 15 & 44.1 \\
\hline $\begin{array}{l}\text { Practice through course audio } \\
\text { media }\end{array}$ & 9 & 27.3 & Listen to the teacher in class & 10 & 29.4 \\
\hline Never practice & 7 & 21.2 & Talk with foreign friends & 6 & 17.6 \\
\hline In class practice & 4 & 12.1 & Practice (general) & 3 & 8.8 \\
\hline
\end{tabular}

Table 5 shows that most (39.4\%) Chinese students used media, such as radio, TV, and films to practice their listening skills.

I listened to songs. I practiced listening by myself.

I listened to the radio, watched TV and movies.

In China, practicing listening using course audio media, such as computerized lessons and conversations was reported as the second most frequent listening strategy (27.3\%) to improve listening. It was noted from the qualitative findings that they received listening exposure of 'American' accents.

I practiced listening to conversations from a computer.

I listened to course conversations from a cassette tape. There are American accent listening exercises.

However, a negative comment on using the course CD for listening practice and their learning improvement was noted.

Students were given a CD by a teacher so that we practiced listening by ourselves. We practiced a lot, but we couldn't speak English. But in Thailand, teachers don't let us practice (with course CD).

In-class practice received $12.1 \%$, while never practice was reported by $21.2 \%$.

I memorized words, never practiced listening and speaking.

I learned only grammar.

In Thailand, practice through media channels was reported as the first listening strategy (44.1\%). This included watching films, listening to the radio and news.

I will use the Internet to improve my English, such as watching English movies and listening to the radio.

Listening to the teacher in-class was reported as the second listening strategy (29.4\%).

I listen attentively and think what they are talking about. Regular practice will make you familiar (with listening to English).

Talking with foreign friends or Thais (17.6\%) was the next listening strategy.

I talk with foreign friends or Thai people. 
In conclusion, regarding the listening strategies, students reported practicing through TV, radio, films and songs as the first listening strategy both in China and Thailand. These learning materials were chosen by the students themselves for out of class practice. However, the second most popular listening strategy in China was changed when they studied in Thailand. They no longer practiced listening using the course CD assigned by the teachers in China for their own listening practice and for acquisition of the American accent. Instead, they practice listening by trying to listen to what the teacher says in class.

\title{
4.1.3 Both Listening and Speaking Strategies
}

Some students reported that both listening and speaking or communication strategies were equally changed. The following are the excerpts from some students' comments.

\begin{abstract}
American or English speaking TV shows may be helpful with new words and listening.
In China, I couldn't speak English. Chinese students didn't speak English that much in China. There are not many schools teaching English. Teachers taught like tutorial (to pass exams). After class, there was no opportunity to practice English. We didn't use English in our daily lives. I felt uncomfortable to speak English, but here in Thailand English is widely used. So in Thailand, in class I am attentive to what the teacher says. I study hard. When I don't understand what the teacher says, I use English to ask her. Also, we use English to do group work.
\end{abstract}

In short, practice of both listening and speaking skills is the learning strategy that some students adopt when they study in Thailand. In China, it is a rare opportunity for them to practice oral communication skills.

\section{Discussions}

The statistical finding revealed that generally speaking, a larger number of Chinese students has significantly changed their English learning strategy use after they have studied in Thailand. There are some interesting points worth discussing as follows.

Firstly and theoretically, language learning strategies are not static, and they can be developed or changed over time. Changes of English learning strategy use depend on a variety of factors. Among them are environment, academic culture, teaching methods, pronunciation of local people and entertainment media. These are considered as contextual factors. Additional learner factors such as learning motivation, survival necessity in a foreign country, and English proficiency of the learners themselves, also contribute to the changes of English learning strategies used by the Chinese students in the present study. Affective factors which are positive attitudes towards English, lower anxiety, selfconfidence and effort to learn and use English, are other aspects which contribute to changes of English learning strategy use (Swatevacharkul, 2011). All of these factors have a casual relationship in changing English learning strategy use.

Secondly, the finding showed that learning strategies related to communication skills, speaking in particular, were the most changed. The only predominant reason was in fact provided by the Chinese students themselves, and it is related to the opportunity for language production. In China, little opportunity is afforded for speaking English as the main focus of English language learning appears to be grammar, not communication skills. When they are situated within a new learning context in Thailand, which puts more emphasis on communicative learning approach than in China and requires them to produce English in their daily lives, they need to adapt themselves to suit with the new learning process and use English to a larger extent as a consequence. English is currently more important and meaningful for them in terms of the necessity of use. This is the reason why $87 \%$ of the Chinese students pointed out that they try to find opportunities to speak English when they are in Thailand.

When they are forced to use English for communication, they need more communication strategies which involve both speaking and listening strategies. This is therefore related to compensation strategies which enable them to use the language for either comprehension or production although they do not have full understanding in language knowledge (Oxford, 1990). These findings saliently support the definition of learning strategy set by Oxford that learning strategies are tools for active, self-directed involvement, which is essential for developing communicative competence which can be developed by realistic interaction with the target language in a meaningful and authentic context.

Thirdly, the findings on the fact that in China these Chinese students tried to speak like native English speakers (17.6\%) as one of the important speaking strategies, should receive attention. The vital reason is that in China strong 
emphasis has been put on a native-like accent especially an American accent. According to the findings, they were required to practice listening by themselves outside of class time with the tape cassette or CD containing English dialogues with English native accents. Therefore, they perceive that the native-like accents, especially American accent, are prestigious. As noted, "In China, we're exposed to an American accent". This might be due to their prior learning experience which exposed them to the native-like accents and formed their perception of the prestigious native-like accent preference. As shown by the research conducted by Moussu (Braine, 2010), the Chinese and Korean students expressed negative feelings toward the non-native speaking teachers more frequently than other students who were from Japan, Argentina, Ecuador, and Switzerland.

Lastly, in regard to the listening strategies, the findings showed that these Chinese students have practiced their listening skills by using media such as radio, TV, films, and the Internet both in China and Thailand. Being in an EFL environment in China and Thailand, these media are considered effective for the language ability development and enjoyment at the same time.

\section{Implications}

In terms of practical implications, three points emerged as follows. Teachers and teaching methodologies can cause change of English learning strategy use; therefore, this raises awareness to the teachers of English that they can help their students use a wider range of learning strategies. Explicit learning strategy teaching is strongly suggested so that students are aware of the learning strategies that they should use and use them on a regular basis.

In regard to a strong preference of American accent, which possibly forms a false assumption of the best, or most prestigious accent and a negative attitude toward other English accents, especially non-native accents, this point needs to be reconsidered. Taking the role of English as a lingual franca (ELF) for purposes in international business and trading and a small number of English native speakers in the world compared to that of the non-native English speakers (Crystal, 1997), it means that greater exposure to English is mainly from non-native English speakers, and the involvement of native speakers in English use is rather limited, or even does not exist, namely in the AEC. This changing phenomenon of the role of English should be explained to these Chinese students so that they can reform their perception and attitude toward English accents. Pronunciation is more important for successful communication than accents.

In addition, students reported that they enjoy using entertainment media to practice their listening and speaking skills. Integration of these entertainment media, such as English songs and movies, into an English course is recommended. Students may be assigned to perform their independent learning outside class time by using these media to improve their English ability.

\section{Recommendations}

1. Replication of this study is recommended using Chinese students in state universities in order to compare the research results.

2. Factors causing changes of English learning strategy use are recommended to study further in order to perceive possible causes and strengthen the existing research findings in this area.

3. Investigation of effects of changes in English learning strategy use on English learning achievement of Chinese students in Thailand is recommended.

4. Further studies should investigate the relationship between the frequency of language learning strategy use and English learning outcomes in order to strengthen the existing research findings in this area.

\section{References}

Braine, G. (2010). Nonnative Speaker English Teachers. New York: Routledge.

Chamot, A.U. (1987). The learning strategies of ESL students. In A. Wenden and J. Rubin (Eds.), Learner Strategies in Language Learning (pp. 71-83). Hertfordshire: Prentice Hall.

Crystal, D. (1997). English as a Global Language. Cambridge: Cambridge University Press.

Gao, X. (2003). Changes in Chinese students' learner strategy use after arrival in the UK: a qualitative inquiry. In D. Palfreyman and R. Smith (Eds.), Learner Autonomy across Cultures: Language Education Perspectives (pp. 41-57). Hampshire: Palgrave Macmillan.

Naewna (2013). Thai international education booming for AEC. Retrieved February, 2013 from http://www. naewna.com/local/41388 
Oxford, R. L. (1990). Language learning strategies: what every teacher should know. New York: Newbury House.

Oxford, R. L. (1994). Language learning strategies: an update. Retrieved March 16, 2012 from http://www.ericdigests.org/19952/update.htm

Rubin, J. (1987). Learner strategies: theoretical assumptions, research history and typology. In A. Wenden and J. Rubin (Eds.), Learner Strategies in Language Learning (pp. 15-30). Hertfordshire: Prentice Hall.

Swatevacharkul, R. (2011). A study of English learning strategies used by Chinese tertiary students in Thailand and factors causing changes of learning strategy use. Unpublished research report. Bangkok: Dhurakij Pundit University.

Wenden, A. (1987). Conceptual background and utility. In A. Wenden and J. Rubin (Eds.), Learner Strategies in Language Learning (pp. 3-13). Hertfordshire: Prentice Hall.

Xinhua News Agency. (2006). Growing number of Chinese students study in Thailand Retrieved February, 2010 from http://www.highbeam.com/doc/1P2-16044301.html

\section{Appendix}

\section{Questionnaire: Comparison of English Learning Strategy Use in Thailand and China}

\section{Please answer the following questions.}

1. In general, do you think your use of English learning strategies has changed from when you were studying English in China? (Please $\sqrt{ }$ )

$$
\text { Yes (Answer every question) }
$$

No

2. In your opinion, how much are your English learming strategies used for each skill listed below while studying in Thailand different from when you were studying in China? (Please rate by making a tick $\checkmark$ in the space provided)

\begin{tabular}{|c|c|c|c|c|c|c|}
\hline & Skills & $\begin{array}{c}\text { Very much } \\
(5)\end{array}$ & $\begin{array}{c}\text { Much } \\
(4)\end{array}$ & $\begin{array}{c}\text { Moderately } \\
(3)\end{array}$ & $\begin{array}{c}\text { Little } \\
(2)\end{array}$ & $\begin{array}{c}\text { Very little } \\
(1)\end{array}$ \\
\hline 1 & Listening & & & & & \\
\hline 2 & Speaking & & & & & \\
\hline 3 & Reading & & & & & \\
\hline 4 & Writing & & & & & \\
\hline 5 & Vocabulary & & & & & \\
\hline
\end{tabular}

3. Based on your answers in Question 2 above regarding the skill for which you have changed your leaming strategies the most, please explain what leaming strategies you used in China and how.

Now (in Thailand) what leaming strategies do you use, and how do you use them for that particular skill?

4. Please explain the causes or factors for changes of your English leaming strategies for that particular skill. 